Proc. Estonian Acad. Sci. Biol. Ecol., 2006, 55, 2, 91-107

\title{
Influence of wood ash on soil chemical composition and biochemical parameters of young Scots pine
}

\begin{abstract}
Malle Mandre
Department of Ecophysiology, Institute of Forestry and Rural Engineering, Estonian University of Life Sciences, Viljandi mnt. 18B, 11216 Tallinn, Estonia; mma@rmk.ee

Received 9 December 2005

Abstract. Short-term effects of different doses $\left(0.25\right.$ and $\left.0.5 \mathrm{~kg} \mathrm{~m}^{-2}\right)$ of wood ash fertilization in a field experiment in a 20-year-old Scots pine stand on a nutrient-poor sandy soil (Arenosol) was studied in North Estonia. Soil chemical properties, nutrient accumulation, soluble carbohydrates, starch, hemicellulose, cellulose, and lignin were used as biochemical indicators for the assessment of the state of trees from 2000 until 2005. Changes in the soil upper horizon $(30 \mathrm{~cm})$ showed an increase in the $\mathrm{pH}$ and in the concentrations of $\mathrm{K}, \mathrm{Ca}, \mathrm{B}, \mathrm{Mg}$, and other elements, except $\mathrm{N}$, after treatment. Statistical relationships were found between the doses of wood ash used in the treatment and the mineral composition of the soil. Changes in soil properties brought about changes in nutrient accumulation into trees and the needle diagnosis showed an essential increase in the $\mathrm{K}, \mathrm{Mg}$, $\mathrm{Fe}, \mathrm{Mn}$, and $\mathrm{Zn}$ concentrations in needles. No statistically significant changes were observed in the concentrations of soluble carbohydrate (tendency to decrease), starch (tendency to increase), and structural carbohydrates, but a somewhat higher accumulation of cellulose and lignin was registered in the needles of Scots pine. The effect of wood ash on carbohydrate metabolism and lignin synthesis seemed to depend on the seasonal development stage of needles and climatic conditions.
\end{abstract}

Key words: wood ash, Pinus sylvestris, soil, needles, nutrients, soluble carbohydrates, starch, hemicellulose, cellulose, lignin.

\section{INTRODUCTION}

In recent years biofuels have become increasingly important worldwide as a present and future alternative to fossil fuels. The National Energy Conservation Programme in Estonia was initiated in 1992 with the aim of converting small heat-only-boilers $(<2 \mathrm{MW})$ in towns and counties throughout the country to the 
use of lower-cost domestic fuels. The proportion of wood and peat in the total fuels used has been increasing from year to year (Yearbook Forest, 2004, 2005). While in 1990 wood was used in the production of primary energy to produce $7885 \mathrm{TJ}$, then by the year 2001 the use of fuelwood had increased almost three times - to 20617 TJ (Statistical Yearbook..., 2002). The increased use of wood and peat in the bioenergy production will lead to an increase in the production of ashes as a type of industrial waste.

Use of wood-based biomass for energy has been a major socio-economic function of forests all over the world. The potential negative impact on the forest ecosystem and the surrounding environment due to an increased utilization of wood-based biomass for energy needs to be mitigated. Possibilities of using ashes in various branches of economy have been rather widely studied worldwide in recent years. Whole-tree harvesting intensifies the build-up of acidity in the soil that is caused by the excess uptake of cations over anions by trees (Olsson et al., 1996). To obtain a more sustainable utilization of biomass fuels, the ash resulting from the combustion of biofuels can be recycled back to the soil. The ecological and biological effects of wood ash recycling are one of the main and very important objectives of scientific investigations in forestry today.

The main attention in the present work was paid to reviewing and improving the present knowledge on the effects of wood ash application to forests. Understanding of the effect of alkaline wood ash on forests and the physiological and biochemical responses of trees makes it possible to recommend wood ash for practical utilization. Changes in carbohydrate concentrations, effects on tree elemental composition, soil reaction, and nutrient availability after the application of wood ash to soil have been used as biochemical indicators to assess the physiological state of trees under alkalization of the growth substrate.

\section{MATERIAL AND METHODS \\ Study area and experiments}

The research site is located in a Scots pine (Pinus sylvestris L.) stand established by sowing in North Estonia (59 $\left.18^{\prime} 26^{\prime \prime} \mathrm{N} ; 24^{\circ} 43^{\prime} 28^{\prime \prime} \mathrm{E}\right)$ in 1982 . The understorey vegetation is dominated by Calluna vulgaris of up to $40 \mathrm{~cm}$, sparse Vaccinium vitis-idaea of up to $10 \mathrm{~cm}$, mosses, and lichens. The landform is flat glacial plain and the soil is Arenosol according to FAO (1990) classification. Sandy soils predominating in the studied area are characterized by low concentrations of $\mathrm{K}$ and $\mathrm{Mg}$ if compared to other regions in Estonia (Petersell et al., 1997). This justifies the use of fertilizers containing $\mathrm{K}$ and $\mathrm{Mg}$ for stimulating the growth of young forests. On the other hand, a forest site on sandy soil was chosen due to the hypothesis that the constituents from the dissolving wood ash would be more mobile (Kahl et al., 1996) and the responses of trees would be more expressive than on other soil types, allowing us to draw conclusions. 
The weather in the experimental area during the years of our investigations, according to the nearest weather station, Harku (10 km SW), was relatively dry, warm, and sunny. The mean monthly amount of precipitation was $54.7 \mathrm{~mm}$; the yearly average of temperature was $6.5^{\circ} \mathrm{C}$.

The experimental sample plots in two replicates with 18 -year-old Scots pine (with an area of $1000 \mathrm{~m}^{2}$ ) were established in June 2000 using different doses of wood ash (WA) for land spreading.

1. Control, without WA;

2. WA $0.25 \mathrm{~kg} \mathrm{~m}^{-2}$;

3. WA $0.50 \mathrm{~kg} \mathrm{~m}^{-2}$.

\section{Wood ash used in the experiments}

The characteristics and chemical composition of WA may be different depending on the fuel incineration technique, additives, and storage conditions (Kofman, 1987). In our experiments raw WA originating from Türi $\left(58^{\circ} 48^{\prime} 22^{\prime \prime} \mathrm{N}\right.$, $25^{\circ} 25^{\prime} 17^{\prime \prime}$ E, Central Estonia) heating plant using for combustion both deciduous and coniferous wood was used. Dry WA was collected from ten places of ash storage at the heating plant and mixed carefully to get homogeneous material for spreading. The same ash was used in all variants and replications. The chemical composition of WA was analysed in the laboratory of the Estonian Environmental Research Centre Ltd., which is competent according to EVS-EN ISO/IEC 17025:2000 to conduct environmental chemical analyses.

The WA used in the field experiments had an average $\mathrm{pH}$ of 12.1-12.6 and its chemical composition was as follows: $\mathrm{N}-250 \mathrm{mg} \mathrm{kg}^{-1}, \mathrm{P}-15500 \mathrm{mg} \mathrm{kg}^{-1}, \mathrm{~S}-$ $10150 \mathrm{mg} \mathrm{kg}^{-1}, \mathrm{Al}-3300 \mathrm{mg} \mathrm{kg}^{-1}, \mathrm{Ba}-1560 \mathrm{mg} \mathrm{kg}{ }^{-1}, \mathrm{Ca}-123000 \mathrm{mg} \mathrm{kg}^{-1}$, $\mathrm{Cu}-197 \mathrm{mg} \mathrm{kg}^{-1}, \mathrm{Fe}-10400 \mathrm{mg} \mathrm{kg}{ }^{-1}, \mathrm{~K}-48000 \mathrm{mg} \mathrm{kg}{ }^{-1}, \mathrm{Mg}-19400 \mathrm{mg} \mathrm{kg}{ }^{-1}$, $\mathrm{Na}-17900 \mathrm{mg} \mathrm{kg}{ }^{-1}, \mathrm{Mn}-9850 \mathrm{mg} \mathrm{kg}{ }^{-1}, \mathrm{~Pb}-76 \mathrm{mg} \mathrm{kg}^{-1}, \mathrm{Zn}-4340 \mathrm{mg} \mathrm{kg}{ }^{-1}$. Although the WA contained virtually no $\mathrm{N}$, its $\mathrm{Ca}, \mathrm{Mg}$, and $\mathrm{K}$ concentrations were high enough to make the material useful for fertilizing forest soils.

\section{Soil analyses}

For interpretation of the physiological state of trees in the experiment the chemical composition of the growth substrate in the sample plots after the application of WA to soil was analysed. Soil samples were collected with a steel bore cylinder from depths of $30 \mathrm{~cm}$, taking into account that approximately $80 \%$ of feeder roots of trees are located in the layer of 10-30 cm (Orlov \& Koshel'nikov, 1971). Soil sampling was carried out seven times in three replications per treatment from August 2000 till October 2001. The nutrient status of the soil upper horizon $(30 \mathrm{~cm})$ prior to the WA application was determined in the Laboratory of Soil Chemistry of the Estonian Control Centre of Plant Production. Standard methods of soil analysis were used: the concentrations of $\mathrm{P}$ and $\mathrm{K}$ were determined by the 
Egner-Riehm double lactate method and that of Ca by the Egner-Riehm-Domingo ammonium acetate-lactate method (ISO/11260, 1995). Total $\mathrm{N}$ was determined by the Kjeldahl method (ISO/11261, 1995); Cu, B, Mn, Zn, and Fe were measured using a Shimadzu atomic absorption/flame emission spectrometer (AA-670), and the $\mathrm{pH}$ of the soil was measured as the potential acidity in $\mathrm{H}_{2} \mathrm{O}$ (ISO/10390, 1994).

\section{Biochemical analyses}

\section{Analyses of the mineral composition of trees}

Current-year needles from ten 20-year-old Scots pines of each treatment variant were used for analyses from 2001 until 2005. Needles were carefully cleaned, cut into small pieces, and oven-dried at $70^{\circ} \mathrm{C}$ to stop metabolic activity (Wilde et al., 1979; Landis, 1985). After grinding, 1-2 g of dried plant material of different organs was chemically analysed in the Laboratory of Plant and Feed Chemistry of the Estonian Control Centre of Plant Production, which is accredited by the Estonian Accreditation Centre from 1999 and has competence according to EVS-EN ISO/IEC 17025:2001. Mineral elements N, P, K, Ca, and Mg regulating the metabolism of carbohydrates and having an importance in biomass formation (Marschner, 1986) were determined. The methods used for analyses are certified by international ringtests including FATAS 2002, AACC, European Grain Network, Estonian/Baltic, etc. Concentrations of metals $(\mathrm{Ca}, \mathrm{K})$ were determined using an atom-adsorption analyser AAA-1N (Karl Zeiss, Jena). For measuring $\mathrm{N}$ the method of Kjeldahl was used, and $\mathrm{P}$ was extracted with vanadium molybdate yellow complex.

\section{Analyses of carbohydrates}

Needles of pine were removed from the shoots and immediately frozen in liquid nitrogen to determine the concentration of non-structural and structural carbohydrates. Total soluble sugar and starch concentrations were estimated using the recommendations by Ferenbaugh (1976), Marshall (1985), and Arasimovich \& Ermakov (1987). All analyses were made at the Plant Production Analyses Laboratory of the Estonian Agricultural Research Centre.

Extraction of soluble sugars was carried out with $80 \%$ ethanol. After centrifugation the soluble supernatant was collected. All residue that remained after the removal of soluble sugars was dried, followed by gelatinization in distilled water, and digestion with 35\% perchloric acid (Ferenbaugh, 1976; Marshall, 1985). The soluble sugars and starch obtained were individually reacted with anthrone reagent $(0.1 \%$ anthrone in $72 \%$ sulphuric acid) to produce a blue-green coloration, and their absorbances were measured spectrophotometrically (Unicam UV-VIS Spectrometry, Great Britain) at $620 \mathrm{~nm}$ (Ferenbaugh, 1976; Peace et al., 1995). Concentrations were calculated using glucose curves as standard. The analyses were carried out in three replications using $1-5 \mathrm{~g}$ dried and homogenized plant material. 


\section{Lignin, cellulose, and hemicellulose analyses}

Lignin, cellulose, and hemicellulose were determined also in the Plant Production Analyses Laboratory of the Estonian Agricultural Research Centre.

The plant material was oven-dried at $70^{\circ} \mathrm{C}$ to stop metabolic activity (Wilde et al., 1979; Landis, 1985), and then ground using a laboratory mill (Tecator Cyclotec) with a screen that will give a particle size $<1 \mathrm{~mm}$. The ground plant material was extracted with acetone $(100 \%)$ at $5^{\circ} \mathrm{C}$ and water at $60-70^{\circ} \mathrm{C}$ to remove sugars, proteins, interfering phenolics, and other soluble compounds. The extraction was repeated several times. The residue was dried and used for the determination of acid detergent fibre (ADF), neutral detergent fibre (NDF), and acid detergent lignin (ADL).

For the determination of fibres Fibertec I \& M Systems (Foss AB, Denmark) elaborated by Van Soest (1987) were used. This method is based on subsequent steps of chemical treatment to solubilize "non-fibre" components and final determination of the residue obtained. Depending on the determination approach, various kinds and amounts of fibre constituents are achieved in the residues.

As the first step, NDF was determined after treatment with a neutral detergent solution (sodium lauryl sulphate and EDTA). The residue consisted of cellulose, hemicellulose, and lignin.

The next step was to determine ADF after the treatment of residue with an acid detergent solution (cetyl trimethylammonium bromide in sulphuric acid solution). The residue was cellulose and lignin.

Finally, ADL was determined after initial treatment for ADF measurement followed by removal of the cellulose fraction through extraction using $72 \% \mathrm{H}_{2} \mathrm{SO}_{4}$. This residue contains only lignin A fraction of acid-soluble lignin and cellulose could be lost during this procedure (Van Soest, 1987; Monties, 1989). Acidresistant residue was recovered by filtration on a glass crucible with an asbestos filter, carefully washed, and dried at $70^{\circ} \mathrm{C}$ for $24 \mathrm{~h}$ to constant weight (Mettler, Switzerland). This acid insoluble residue is insoluble lignin (hereafter called lignin) (Monties, 1989). After weighing the residue was ashed at $525 \pm 25^{\circ} \mathrm{C}$ for at least $5 \mathrm{~h}$, and lignin was calculated after correcting for mineral elements (Van Soest, 1987).

Simple subtraction rules were used to calculate cellulose and hemicellulose: $\mathrm{ADF}-\mathrm{ADL}=$ cellulose and $\mathrm{NDF}-\mathrm{ADF}=$ hemicellulose. The results for lignin, cellulose, and hemicellulose were expressed as percentage of dry mass of plant material (\% d.m.).

\section{Statistical analyses}

Regression trendlines and the determination coefficient $\left(R^{2}\right)$ were calculated using Statgraphics and Microsoft Excel 2000 (Sachs, 1982). To analyse differences in the concentrations of pigments between the control trees and trees under treatment, the $t$-test was used (Girden, 1992). Significance ( $p$ ) of differences was accepted at $p<0.05$. 


\section{RESULTS AND DISCUSSION}

\section{Changes in soil}

Wood ash consists of inorganic minerals and organic compounds remaining in the ash because of incomplete combustion. Nitrogen, which volatalizes during combustion, may be found only in very small amounts, but all the macronutrients occur in the ash. The major proportion of the minerals in the ash is a mixture of oxides, hydroxides, silicates, and carbonates of the base-forming cations. Some of the oxides and hydroxides in the ash dissolve easily in water and produce a strong alkaline reaction (liming effect) (Ljung \& Nordin, 1997). The water solution of WA has $\mathrm{pH} 12.1-12.6$. As the dose of WA was increased in different variants, a linear increase in the average soil $\mathrm{pH}(n=10)$ was found during 2000 until 2004 (Figs 1 and 2). The difference from the $\mathrm{pH}$ of the control soil was not greater than $0.3-0.8 \mathrm{pH}$ units on average. The effect of raw WA on the $\mathrm{pH}$ in the upper horizon of soil persists for a rather long time but there is a slight reduction in the $\mathrm{pH}$ level after three years in sandy soil where our experimental plots were located.

The solubility and the potential availability of the macronutrients to plants in the ash are high, with the possible exception of $\mathrm{P}$, and follow the order $\mathrm{K}>\mathrm{Mg}>\mathrm{Ca}>\mathrm{P}$ (Eriksson, 1998). In our experiments elevated $\mathrm{K}$ concentrations were observed in the soil of the plots treated with WA in all treatments. A 2-3 times increase in the $\mathrm{K}$ concentration, 5 times in $\mathrm{Mg}$, and 9 times in $\mathrm{Mn}$ concentration occurred in the variant of treatment with $0.5 \mathrm{~kg} \mathrm{~m}^{-2}$ (Fig. 2). Also the B concentration in the soil was $50 \%$ and $\mathrm{Ca}$ approximately $32 \%$ higher than control in this variant. In all variants of treatment $\mathrm{Cu}, \mathrm{Zn}$, and $\mathrm{Fe}$ were higher than control.

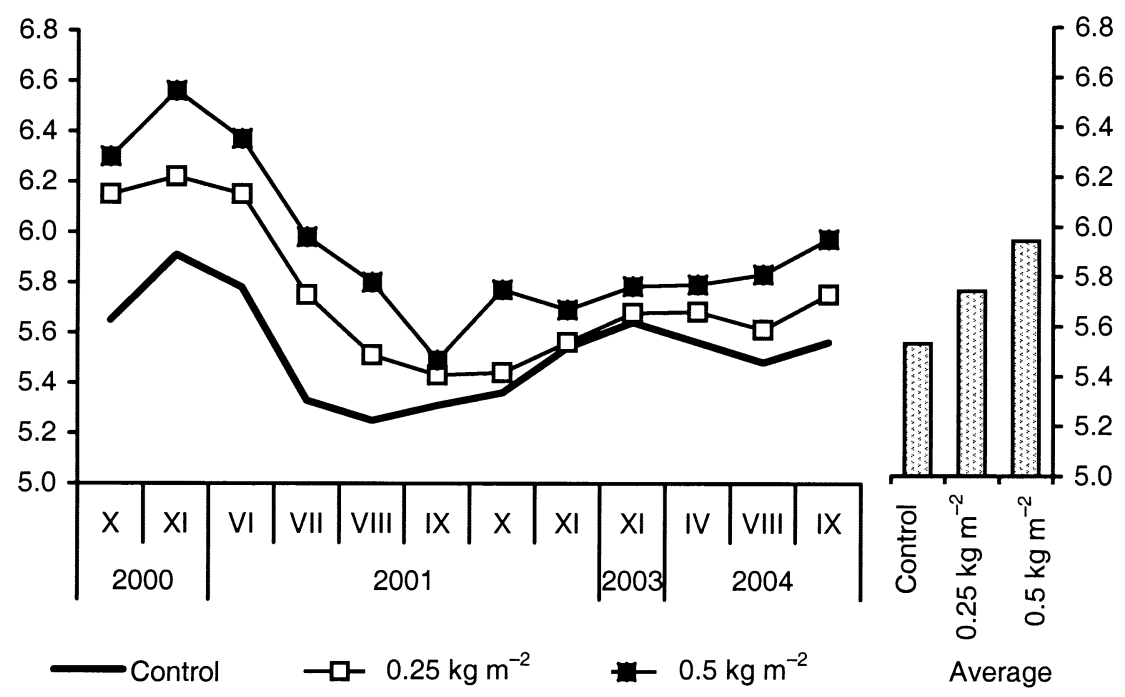

Fig. 1. Seasonal dynamics of the soil $\mathrm{pH}$ after application of different amounts of wood ash to soil. 

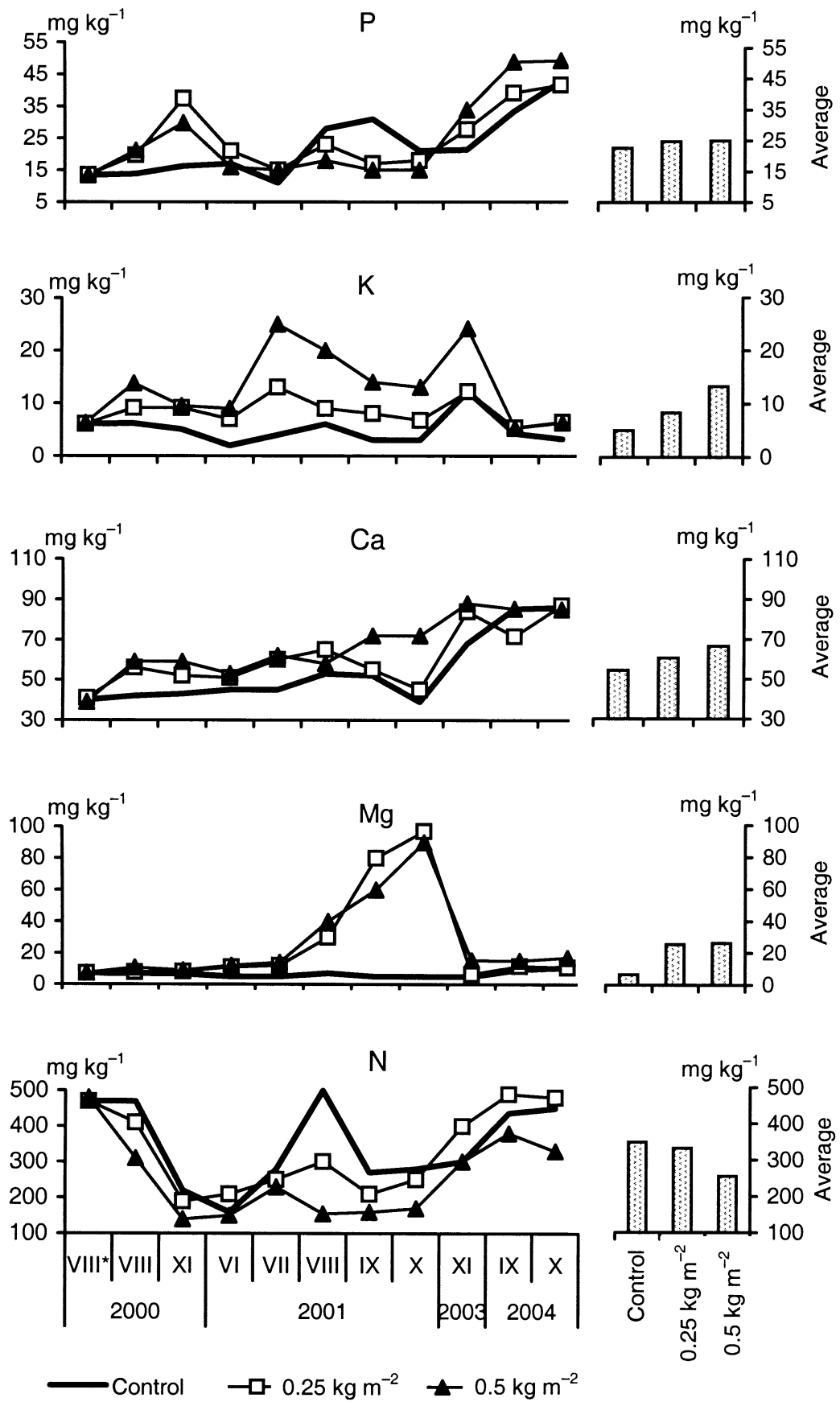

Fig. 2. Seasonal dynamics and mean contents of mineral elements in soil after wood ash application. 
Depending on the amounts of WA applied and the consequent rise in the soil $\mathrm{pH}$, the concentrations of $\mathrm{N}$ decrease in the upper soil layers (Fig. 2). Fritze et al. (1994) reported lowered $\mathrm{N}$ concentrations similar to those measured in our experiments. Similar tendencies were also noted by Bramryd \& Fransman (1995) even 10 years after applying loose ash on a coniferous site in South Sweden, and the authors concluded that the increased $\mathrm{pH}$ had stimulated immobilization of $\mathrm{N}$. The decrease of $\mathrm{N}$ pools in limed soils may result from changes in mineralization or nitrification processes described by many authors (Martikainen, 1985; Eriksson, 1996; Högbom et al., 2000; Arvidsson, 2001; Bäckman \& Klemedtsson, 2003). Although WA has been appreciated as a liming agent as well as a source of P and micronutrients (Clapham \& Zibilske, 1992), an increase of the soil $\mathrm{pH}$ might decrease the mobility of various elements in soil. In our experiments a decrease in $\mathrm{P}$ available to plants was observed in the variant treated with $0.5 \mathrm{~kg} \mathrm{~m}^{-2}$ WA during two years after treatment while later an increase in P occurred. Temporal changes in $\mathrm{P}$ concentrations might be connected with physical and chemical processes in soil (Kärblane, 1996) and also result from microbiological activity (Büttner et al., 1998) and increased phosphatase activity in soil (Clarholm, 1994). Due to the biological, chemical, and physical processes in soil that involve $\mathrm{P}$, the interpretation of changes in $\mathrm{P}$ availability need special studies in the future. Regression analysis revealed strong relationships between the soil $\mathrm{pH}$ and WA doses $\left(R^{2}=0.8771\right)$. Differences from the control were found for $\mathrm{K}$ in the variant treated with $0.25 \mathrm{~kg} \mathrm{~m}^{-2}(p=0.016)$ and with $0.5 \mathrm{~kg} \mathrm{~m}^{-2}(p=0.001)$, for Mn also in both variants ( $p=0.007$ and $p=0.009$, respectively). For Fe and Ca, differences from the control were established only in the case of the higher WA dose ( $p=0.002, p=0.05$, respectively).

The $\mathrm{pH}$ of the soil water collected from lysimeters had also risen: at a depth of $30 \mathrm{~cm}$ it was 5.9 in the control variant and in the variants treated with 0.25 and $0.5 \mathrm{~kg} \mathrm{~m}^{-2}$ respectively 6.4 and 7.1. We found an increase of $\mathrm{Ca}^{2+}, \mathrm{Mg}^{2+}$, and $\mathrm{K}^{+}$ in the soil solution, which is supported by the findings of Arvidsson (2001) and Rumpf et al. (2001).

\section{Mineral elements in needles}

Wood ash application to soil caused deviations in the mineral composition of Scots pine needles. Except for N and S, WA contains mineral nutrients in almost the same proportions as live trees, and alterations in nutrient composition would be expected for elements added with WA to soil. A substantial increase in the average $\mathrm{K}$ concentration in current-year needles was found in the investigated trees in each variant of treatment (Table 1, Fig. 3). Although the Ca concentration in WA and in soil is relatively high, it decreases in the needles about $14 \%$ and $19 \%$ from the control in the treatments of 0.25 and $0.5 \mathrm{~kg} \mathrm{~m}^{-2}$. It should be stressed that in alkalized soils and after treatment of soil with WA the physiological antagonism between $\mathrm{Ca}$ and $\mathrm{K}$ in mineral nutrition processes of plants may deepen, and at high concentrations of $\mathrm{K}$ in plants the accumulation of $\mathrm{Ca}$ may become inhibited (Miidla, 1984; Saarela, 1991; Mandre, 1995; Demeyer et al., 2001). 
Table 1. The mean content of elements in Scots pine current-year needles after treatment with wood ash, 2001-2002

\begin{tabular}{c|r|r|r}
\hline \multirow{2}{*}{ Element } & \multicolumn{3}{|c}{ Variant } \\
\cline { 2 - 4 } & Control & $0.25 \mathrm{~kg} \mathrm{~m}^{-2}$ & $0.5 \mathrm{~kg} \mathrm{~m}^{-2}$ \\
\hline \% & & & \\
$\mathrm{N}$ & 1.443 & 1.453 & 1.493 \\
$\mathrm{~K}$ & 0.406 & 0.578 & 0.615 \\
$\mathrm{Ca}$ & 0.338 & 0.290 & 0.273 \\
$\mathrm{P}$ & 0.144 & 0.149 & 0.154 \\
$\mathrm{~B}$ & 12.125 & 18.550 & 16.488 \\
$\mathrm{~S}$ & 0.068 & 0.071 & 0.149 \\
$\mathrm{C}$ & 1.847 & 2.030 & 2.008 \\
$\mathrm{mg} \mathrm{kg}$ & & & \\
$\mathrm{Fe}$ & 38.038 & 40.325 & 36.650 \\
$\mathrm{Mn}$ & 524.750 & 688.000 & 663.380 \\
$\mathrm{Zn}$ & 36.900 & 39.363 & 39.350 \\
$\mathrm{Cu}$ & 3.401 & 3.391 & 3.811 \\
$\mathrm{Mg}$ & 0.079 & 0.079 & 0.080
\end{tabular}

The main function of the biogenic elements $\mathrm{N}$ and $\mathrm{P}$, which serve as constituents of proteins and nucleic acid, is quite evident and readily described. Although the average concentrations of $\mathrm{P}$ and $\mathrm{N}$ did not have statistically significant differences from the control, they had a tendency to be elevated by $1-5 \%$ in the Scots pine needles in the plots treated with WA (Table 1, Fig. 3). Considering that currentyear needles use for growth $\mathrm{N}$ and $\mathrm{P}$ from older needles, the rising tendency of these elements in current-year needles may be due to translocation from older needles.
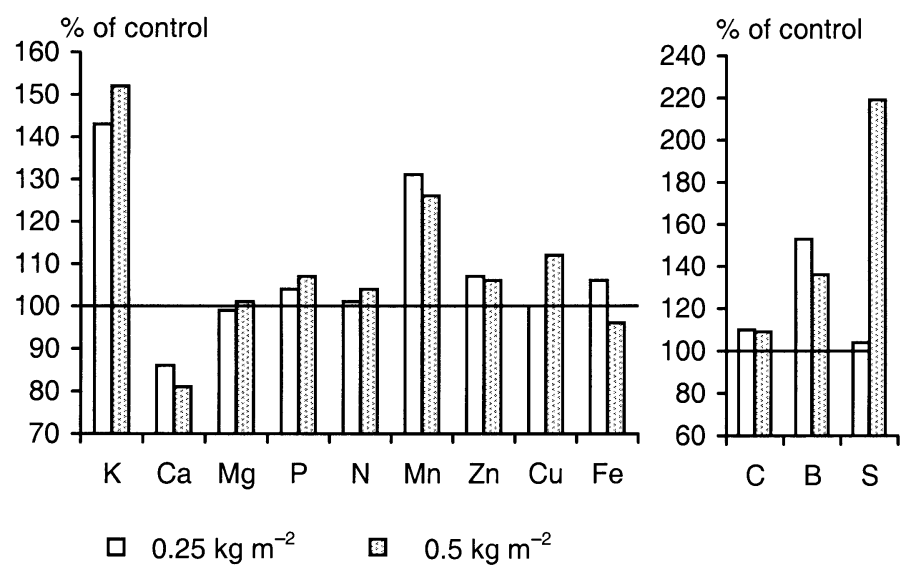

Fig. 3. Mean content of mineral elements in current-year Scots pine needles after wood ash application (\% of control). 
Three variants $\left(0,0.25\right.$, and $\left.0.5 \mathrm{~kg} \mathrm{~m}^{-2}\right)$ were introduced into regression equations computed. Statistically significant relationships $(p<0.05)$ were found between the concentrations in the soil and in the needles for $\mathrm{K}\left(R^{2}=0.8233\right)$, Mn $\left(R^{2}=0.6722\right)$, and $\mathrm{B}\left(R^{2}=0.6334\right)$. Relationships between the soil $\mathrm{pH}$ and the elemental composition and nutrients in the current-year needles were found for $\mathrm{K}\left(R_{\mathrm{pH}}^{2}=0.8788, R_{\mathrm{K}}^{2}=0.8346\right), \mathrm{Mg}\left(R_{\mathrm{pH}}^{2}=0.5552, R_{\mathrm{Mg}}^{2}=0.5848\right)$, and $\mathrm{Ca}$ $\left(R_{\mathrm{pH}}^{2}=0.6731, R_{\mathrm{Ca}}^{2}=0.6530\right)$.

Comparison with the control revealed that WA application had no essential influence on the concentrations of heavy metals such as $\mathrm{Fe}$ and $\mathrm{Cu}$ in current-year needles, but a $6.7 \%$ increase as compared with the control was observed in the $\mathrm{Zn}$ concentration. Regression analysis showed a statistical relationship between $\mathrm{Zn}$ in soil and in needles $\left(R^{2}=0.5375\right)$.

\section{Changes in carbohydrate metabolism and lignin in needles}

Few studies have been made on the effect of WA on the biochemistry and physiology of plants. It is only possible to make assumptions about the physiological responses to WA relying on our knowledge and research results on the effect of several other substances used widely for liming (e.g. cement dust, limestone dust, etc.) and by drawing parallels to find out relationships between biochemical processes.

Investigation of the dynamics of soluble carbohydrates and starch in the currentyear needles of Scots pine showed that treatment with WA did not cause essential changes in their concentration. Depending on climatic factors, the seasonal dynamics of the concentration of soluble carbohydrates in the current-year needles was similar in the control variant and the variants treated with WA. However, mean indicators of annual dynamics indicate decreasing concentration of soluble carbohydrates, which in developing needles was observed mainly in summer in June-July and in late autumn in October-November. No statistically significant differences in soluble carbohydrate concentrations were observed between different variants of treatment. Although studies by Klõšeiko (2003) indicate decreasing concentrations of glucose and fructose in pine needles in WA treated experiments, we failed to find significant differences from the control in the total concentration of soluble carbohydrates.

The starch concentration in the current-year needles of Scots pine showed a similar seasonal dynamics in all variants. Some increase in the starch accumulation in the WA treated trees was found in early spring before budbreak (Fig. 4).

The results obtained regarding the impact of WA on the concentration of lignin in Scots pine needles showed that the response reactions to different WA doses were clearest in autumn. Our results indicated that the rise of the soil $\mathrm{pH}$ due to WA application stimulated the accumulation of lignin in needles while no statistically significant differences from the control were observed in the first two 

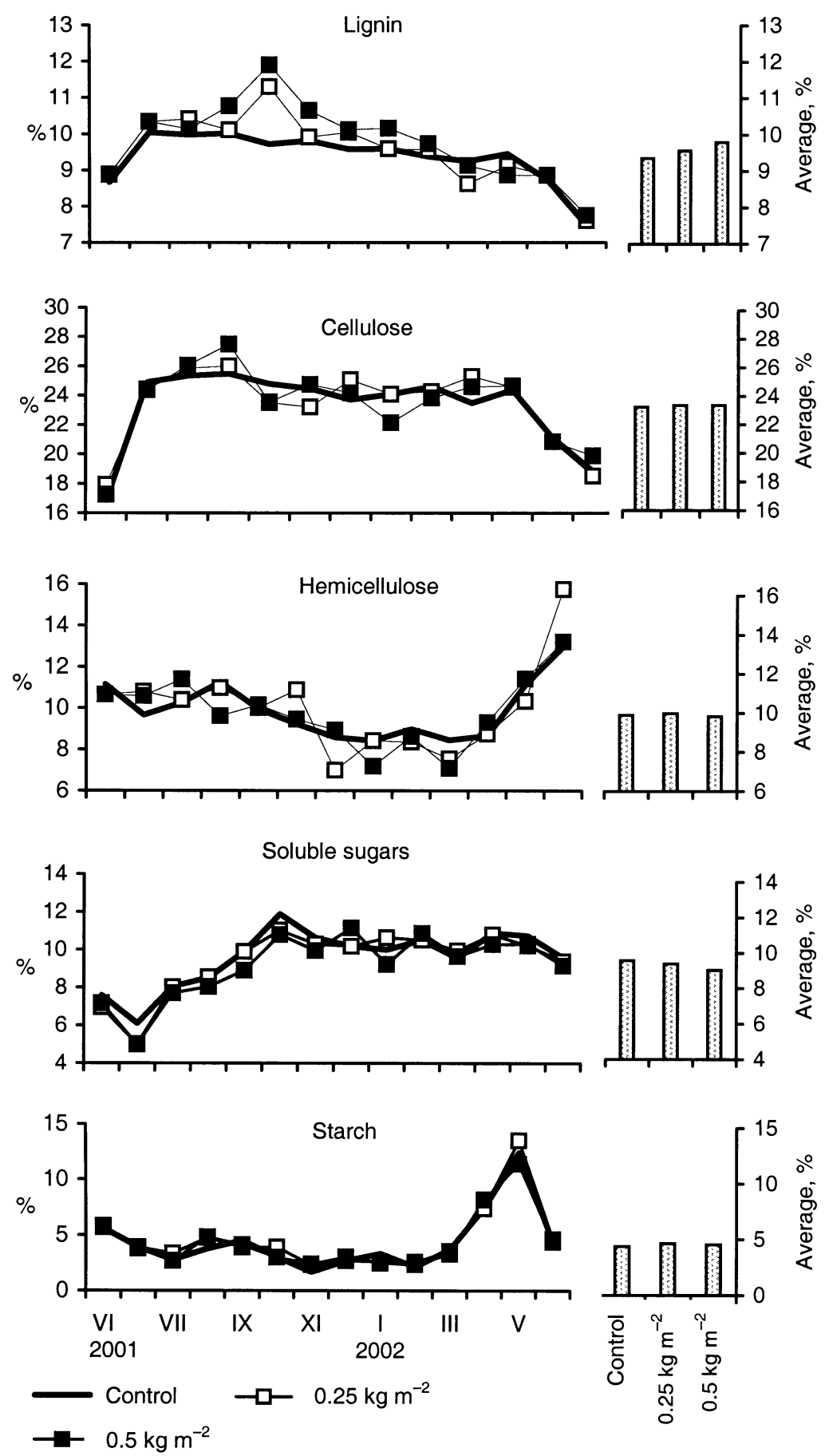

Fig. 4. Seasonal dynamics of lignin, cellulose, hemicellulose, soluble sugars, and starch and their mean contents in current-year needles of Scots pine at different amounts of wood ash application to soil. 
years after treatment (Fig. 4). Statistically significant differences ( $t$-test) from the control lignin concentration were established for needles in the period from July to December $(p=0.052)$. After five years, in 2005, an increase in the lignin average concentration by about $2-7 \%$ of control was found in the current-year needles.

The concentration of cellulose did not change significantly in the needles of trees treated with WA either. In the first year after treatment the differences from control did not exceed 2-6\% (Fig. 4). A statistically significant difference ( $t$-test) from control in the cellulose concentration was established only in July and August $2001(p=0.026)$ in the variant treated with $0.5 \mathrm{~kg} \mathrm{~m}^{-2} \mathrm{WA}$. After five years (in 2005) of treatment no statistical differences from control were found in the cellulose concentration of needles in either variant of treatment.

It is known that hemicelluloses in plants are not only structural compounds but they may serve as a reserve of carbohydrates (Glerum \& Balatinecz, 1980; Kozlowski et al., 1991). The contribution of the reserves of hemicelluloses to new growth has been little studied. Renault \& Zwiazek (1997) favour the explanation that after the resumption of growth following winter dormancy, the changes in the composition of hemicelluloses adjust the cell wall elasticity rather than supply energy for growth. One cannot exclude the possibility that the heartwood sugars originate from cell wall hemicelluloses during heartwood formation by the action of hemicellulases (Magel et al., 1997). This suggests that hemicelluloses may be the most strongly affected by changes within the plant as well as by the environmental factors. The average concentration of hemicelluloses seemed to increase under the influence of WA and is 5-9\% of control in the needles in the variant treated with $0.25 \mathrm{~kg} \mathrm{~m}^{-2}$ (Fig. 4). In the variant with $0.25 \mathrm{~kg} \mathrm{~m}^{-2}$ WA added to the soil the differences from control were relatively large $(p=0.015)$. Later, in 2005 , only a $6 \%$ higher concentration of hemicellulose than in control and no differences in the average hemicellulose concentrations in needles were found in the variant treated with $0.5 \mathrm{~kg} \mathrm{~m}^{-2}$.

The results obtained and information found in the literature allow us to state that structural compounds in plants are not unchangeable in needles after treatment with WA. Still, their concentration may vary depending on the development level and age of the organs/needles (Miidla et al., 1989; Padu et al., 1989), seasonal changes and characteristics of the growth substrate (Mandre, 2002).

Carbon is the most important component of organic molecules, making up on average $45 \%$ of the organic dry mass. As the changes in the concentrations of soluble and structural carbohydrates and lignin in plants treated with WA are rather modest, the stability of carbon in the current-year needles guarantees to some extent the synthesis of the above-treated compounds. Similarly to N and P, translocation of $\mathrm{C}$ from older needles to younger ones can be assumed. As compared to the younger needles a falling tendency of $\mathrm{C}$ in older needles was identifiable in 2005 (Fig. 3). 


\section{CONCLUSIONS}

Several changes in the chemical composition of nutrient poor sandy soil appeared after application of wood ash. Wood ash usually increases the $\mathrm{pH}$ and base saturation in the $\mathrm{O}$ horizon, which is described to be more drastic if raw ash is used (Bramryd \& Fransman, 1995; Saarsalmi et al., 2001; Arvidsson \& Lundkvist, 2003). In soil an increase was observed in the concentration of almost all nutrients except $\mathrm{N}$. It is evident that the enrichment and altered mineral composition of soil may cause changes in the metabolism and physiological activity of trees in general. Although earlier studies on needle chemistry in Scots pine have revealed no or rather small and transient effects on $\mathrm{Ca}$ and $\mathrm{K}$ after wood ash treatments (Moilanen \& Issakainen, 2000; Vuorinen \& Kurkela, 2000; Jacobson, 2001), experiments showed an increase of $\mathrm{K}, \mathrm{B}, \mathrm{Mg}, \mathrm{Fe}$, and $\mathrm{Zn}$ in tissues of Scots pine needles. Wood ash amendment in tree stands on mineral soils usually does not give any positive growth response in the stand (Sikström, 1992; Jacobson, 2001; Saarsalmi et al., 2004). Ots \& Haugas (2004) showed even a decrease of needle biomass.

However, changes in the mineral composition of soil and trees usually result in serious alterations in plant metabolism. Increase of $\mathrm{Mg}$ and $\mathrm{Fe}$ in the needles under the influence of wood ash may favour biosynthesis of pigments participating in photosynthesis (Mandre \& Korsjukov, 2004; Mandre et al., 2004). Changes in $\mathrm{K}$ and $\mathrm{P}$ concentrations may alter several pathways in plant metabolism. Potassium balances the charges of organic acids (Marschner, 1986) and is known to participate as a cofactor at least in 50 different enzymatic reactions in plants (Buchanan et al., 2000); for example, in chlorophyll synthesis, photosynthesis, and carbohydrate metabolism (Reddy et al., 1998; Gonzali et al., 2001). To build up lignin and structural carbohydrates from carbon skeletons provided by photosynthesis, a coordinated interaction of several metabolic pathways and energy is required. In the biosynthesis of structural carbohydrates and lignin, hexoses play a great role. Klõšeiko (2003) investigated dose-response relationships in carbohydrate metabolism in Norway spruce after application of several doses of wood ash to the soil and concluded that the concentration of hexoses corresponds to the dynamic changes in the soil $\mathrm{pH}$ and that the changes in carbohydrates have a seasonal character. The present study showed that in July the concentration of soluble carbohydrates decreased in harmony with the applied wood ash amounts. This agrees with the findings of Klõšeiko (2003) about glucose dynamics in Norway spruce. However, at the end of summer and in early autumn, the effect of wood ash did not depend on the amounts applied. Next spring the concentrations of soluble carbohydrates were obviously decreased by wood ash. In the present study the changes in the concentrations of structural carbohydrates and lignin in the needles of 20-year-old Scots pine under the influence of increased $\mathrm{pH}$ and changed mineral composition of soil after wood ash application to soil were found not to be statistically significant in the first two years after treatment. After five years some increase of lignification in needles was observed. However, the mechanisms 
through which wood ash application to soil affects plants are not fully understood and need further studies.

From the standpoint of forestry, the chemical composition of wood is undoubtedly significant as it determines the industrial quality of wood. Although in the Scots pine treated with wood ash certain quantitative shifts in the lignin, cellulose, and hemicellulose concentrations in needles were established, the changes in the stems, which are directly used in the forest industry, need to be studied for drawing final conclusions about the mechanisms of the effect and making recommendations of wood ash application for practical use.

\section{ACKNOWLEDGEMENTS}

Support to this research was provided by the Estonian Science Foundation (grants Nos 4725 and 6022) and the Estonian Ministry of Education and Research (project No. 0432153s02).

\section{REFERENCES}

Arasimovich, V. V. \& Ermakov, A. I. 1987. Measurement of polysaccharides and lignin. In Methods for Biochemical Studies of Plants (Ermakov, A. I., ed.), pp. 166-170. Agropromizdat, Leningrad (in Russian).

Arvidsson, H. 2001. Wood Ash Application in Spruce Stands. Effects on Ground Vegetation. Tree Nutrient Status and Soil Chemistry. PhD Thesis. Swedish University of Agricultural Sciences.

Arvidsson, H. \& Lundkvist, H. 2003. Wood ash application to young Norway spruce stands shortly after clearfelling - effects on soil water chemistry. In Wood Ash Application in Spruce Stands. PhD Thesis (Arvidsson, H.). Silvestria, 221. Swedish University of Agricultural Sciences.

Bäckman, J. S. K. \& Klemedtsson, Å. K. 2003. Increased nitrification in acid coniferous forest soil due to high nitrogen deposition and liming. Scand. J. For. Res., 18, 514-524.

Bramryd, T. \& Fransman, B. 1995. Silvicultural use of wood ashes - effects on the nutrient and heavy metal balance in a pine (Pinus sylvestris L.) forest soil. Water Air Soil Pollut., 85, 1039-1044.

Buchanan, B. B., Gruissem, W. \& Jones, R. L. 2000. Biochemistry and Molecular Biology of Plants. American Society of Plant Physiologists, Rockville.

Büttner, G., Gering, C., Nell, U., Rumpf, S. \& von Wilpert, K. 1998. Einsatz von Holzasche in Wäldern. Forst Holz, 53, 72-76.

Clapham, W. M. \& Zibilske, L. M. 1992. Wood ash as a liming amendment. Commun. Soil Sci. Plan., 23, 1209-1227.

Clarholm, M. 1994. Granulated wood ash and a 'N-free' fertilizer to a forest soil - effects on P availability. For. Ecol. Manage., 66, 127-136.

Demeyer, A., Voundi Nkana, J. C. \& Verloo, M. G. 2001. Characteristics of wood ash and influence on soil properties and nutrient uptake: an overview. Biores. Technol., 77, 287-295.

Eriksson, H. 1996. Effects of tree species and nutrient application on distribution and budgets of base cations in Swedish forest ecosystems. PhD thesis. Silvestria, 2. Swedish University of Agricultural Sciences.

Eriksson, J. 1998. Dissolution of hardened wood ashes in forest soils: studies in a column experiment. Scan. J. For. Res. Suppl., 2, 23-32. 
Ferenbaugh, W. R. 1976. Effects of simulated acid rain on Phaseolus vulgaris L. (Fabaceae). Am. J. Bot., 63, 283-288.

Fritze, H., Smolander, A., Levula, T., Kitunen, V. \& Mälkönen, E. 1994. Wood-ash fertilization and fire treatments in a Scots pine forest stand: effects on the organic layer, microbial biomass, and microbial activity. Biol. Fert. Soils, 17, 57-63.

Girden, E. R. 1992. ANOVA: Repeated Measures. Sage Publications, Newbury Park, California.

Glerum, C. \& Balatinecz, J. J. 1980. Formation and distribution of food reserves during autumn and their subsequent utilization in jack pine. Can. J. Bot., 58, 40-54.

Gonzali, S., Pistelli, L., De Bellis, L. \& Alpi, A. 2001. Characterization of two Arabidopsis thaliana fructokinases. Plant Sci., 160, 1107-1114.

Högbom, L., Nohrstedt, H.-Ö. \& Nordlund, S. 2000. Tillförsel av vedaska gav surare och mer kväverikt markvatten / Lower $\mathrm{pH}$ and more nitrogen in soil water after spreading of wood ash. SkogForsk Resultat, 6, 1-2.

ISO/10390. 1994. Soil Quality - Determination of $\mathrm{pH}$.

ISO/11260. 1995. Soil Quality - Determination of CEC and Base Saturation.

ISO/11261. 1995. Soil Quality - Determination of Total Nitrogen. Modified Kjeldahl Method.

Jacobson, S. 2001. Fertilization to increase and sustain tree growth in coniferous stand in Sweden. $\mathrm{PhD}$ thesis. Silvestria, 217. Swedish University of Agricultural Sciences.

Kahl, J. S., Fernandez, I. J., Rustad, L. E. \& Peckenham, J. 1996. Threshold application rates of wood ash to an acidic forest soil. J. Envir. Qual., 25, 220-227.

Kärblane, H. (comp.). 1996. Taimede toitumise ja väetamise käsiraamat. Põllumajandusministeerium, Tallinn.

Klõšeiko, J. 2003. Carbohydrate Metabolism of Conifers in Alkalised Growth Conditions. Doctoral dissertation. Estonian Agricultural University, Tartu.

Kofman, P. 1987. Wood-Ashes from Chip Fuelled Heating Plants: Chemical Composition, Possibilities of Application. Danish Inst. For. Technol., Hørsholm, Denmark (in Danish with English summary).

Kozlowski, T. T., Kramer, P. J. \& Pallardy, S. G. 1991. The Physiological Ecology of Woody Plants. Academic Press, San Diego, New York.

Landis, T. D. 1985. Mineral nutrition as an index of seedling quality. In Evaluating Seedling Quality: Principles, Procedures, and Predictive Abilities of Major Tests (Duryea, M. L., ed.), pp. 29-48. Forest Research Laboratory, Oregon State University, Corvallis.

Ljung, A. \& Nordin, A. 1997. Theoretical feasibility for ecological biomass ash recirculation: chemical equilibrium and heavy metals during combustion. Environ. Sci. Technol., 31, 2499-2503.

Magel, E., Hillinger, C., Höll, W. \& Ziegler, H. 1997. Biochemistry and physiology of heartwood formation: role of reserve substances. In Trees - Contributions to Modern Tree Physiology (Rennenberg, H., Eschrich, W. \& Ziegler, H., eds), pp. 477-506. Backhuys Publishers, Leiden.

Mandre, M. 2002. Relationships between lignin and nutrients in Picea abies L. under alkaline air pollution. Water Air Soil Pollut., 133, 363-379.

Mandre, M. 1995. Changes in the nutrient composition of trees. In Dust Pollution and Forest Ecosystems. A Study of Conifers in an Alkaline Environment. Publ. Inst. Ecol., 3 (Mandre, M., ed.), pp. 44-65. Tallinn.

Mandre, M. \& Korsjukov, R. 2004. Puutuha mõju hariliku männi (Pinus sylvestris) okaste mineraalsele koostisele ja pigmentkompleksile. Metsanduslikud uurimused, 40, 92-100.

Mandre, M., Korsjukov, R. \& Ots, K. 2004. Effect of wood ash on the biomass distribution and physiological state of Norway spruce seedlings on sandy soils. Plant Soil, 265, 301-314.

Marschner, H. 1986. Mineral Nutrition of Higher Plants. Academic Press, London.

Marshall, J. D. 1985. Carbohydrate status as a measure of seedling quality. In Evaluating Seedling Quality: Principles, Procedures, and Predictive Abilities of Major Tests (Duryea, M. L., ed.), pp. 49-58. Forest Research Laboratory, Oregon State University, Corvallis. 
Martikainen, P. J. 1985. Numbers of autotrophic nitrifiers and nitrification in fertilized forest soil. Soil Biol. Biochem., 17, 245-248.

Miidla, H. 1984. Taimefüsioloogia. Valgus, Tallinn.

Miidla, H., Padu, E. \& Tänav, A. 1989. Regulation of lignin formation in wheat stalks. In Publications in Plant Physiology and Plant Biochemistry, 5. The Formation of Lignin in Wheat Plants and Its Connection with Mineral Nutrition. Acta Comm. Univ. Tartu., 845, pp. 53-68. Tartu.

Moilanen, M. \& Issakainen, J. 2000. Tuhkalannoituksen metsävaikutukset. Metsätehon raportti, 93.

Monties, B. 1989. Lignins. In Methods in Plant Biochemistry (Dey, P. M. \& Harborne, J. B., series eds). Plant Phenolics. Vol. 1 (Harborne, J. B., ed.), pp. 113-157. Academic Press, London.

Olsson, B. A., Bengtsson, J. \& Lundkvist, H. 1996. Effects of different forest harvest intensities on the pools of exchangeable cations in coniferous forest soils. For. Ecol. Manage., 84, 135-147.

Orlov, A. J. \& Koshel'nikov, S. P. 1971. Soil Ecology of Scots Pine. Nauka, Moskva (in Russian).

Ots, K. \& Haugas, R. 2004. Puutuhaga väetamise mõju hariliku männi (Pinus sylvestris L.) okkamassi formeerumisele. Metsanduslikud uurimused, 40, 101-109.

Padu, E., Meiner, L. \& Selgis, R. 1989. The activity of L-phenylalanine ammonia-lyase and peroxidase, and the biosynthesis of phenolic compounds in wheat under different condition of mineral nutrition. In The Formation of Lignin in Wheat Plants and Its Connection with Mineral Nutrition. Publications in Plant Physiology and Plant Biochemistry, 5. Acta Comm. Univ. Tartu., 845, pp. 85-108. Tartu.

Peace, E. A., Lea, P. J. \& Darrall, N. M. 1995. The effect of open-air fumigation with $\mathrm{SO}_{2}$ and $\mathrm{O}_{3}$ on carbohydrate metabolism in Scots pine (Pinus sylvestris) and Norway spruce (Picea abies). Plant Cell Environ., 18, 277-283.

Petersell, V., Ressar, H., Carlsson, M., Mõttus, V., Enel, M., Mardla, A. \& Täht, K. 1997. The Geochemical Atlas of the Humus Horizon of Estonian Soil. Explanatory text. Geological Survey of Estonia, Geological Survey of Sweden, Tallinn, Uppsala.

Reddy, K. R., Hodges, H. F. \& Varco, J. 1998. Potassium Nutrition of Cotton. Bulletin, 1904. Mississippi Agricultural and Forestry Experiment Station, Mississippi.

Renault, S. \& Zwiazek, J. J. 1997. Cell wall composition and elasticity of dormant and growing white spruce (Picea glauca) seedlings. Physiol. Plant., 101, 323-327.

Rumpf, S., Ludwig, B. \& Mindrup, M. 2001. Effect of wood ash on soil chemistry of a pine stand in Northern Germany. J. Plant Nutr. Soil Sci., 164, 569-575.

Saarela, I. 1991. Wood, bark, peat and coal ashes as liming agents and sources of calcium, magnesium, potassium and phosphorus. Ann. Agric. Fenn., 30, 375-388.

Saarsalmi, A., Mälkönen, E. \& Piirainen, S. 2001. Effects of wood ash fertilization on forest soil chemical properties. Silva Fenn., 35, 355-368.

Saarsalmi, A., Mälkönen, E. \& Kukkola, M. 2004. Effects of wood ash fertilization on soil chemical properties and stand nutrient status and growth of some coniferous stands in Finland. Scand. J. For. Res., 19, 217-233.

Sachs, L. 1982. Applied Statistics. A Handbook of Techniques. Springer, New York.

Sikström, U. 1992. Stem growth of Scots pine and Norway spruce on mineral soils after treatment with a low lime dose, nitrogen fertilizer and wood ash. Institutet för Skogsförbättring, Rapport, 27.

Statistical Yearbook of Estonia 2002. 2002. Tallinn, Statistical Office of Estonia.

Van Soest, P. J. 1987. Nutritional Ecology of the Ruminant. Ruminant Metabolism, Nutritional Strategy, the Cellulytic Fermentation and the Chemistry of Forages and Plant Fibers. Cornell University Press, Ithaca, London.

Vuorinen, M. \& Kurkela, T. 2000. Lophodermella sulcigena infection in Scots pine needles and tree nutrition. Forestry, 73, 239-246.

Wilde, S. A., Corey, R. B., Iyer, J. G. \& Voight, G. K. 1979. Soil and Plant Analysis for Tree Culture. Oxford and IBH Publishing Co., New Dehli.

Yearbook Forest. 2004. Metsakaitse- ja Metsauuenduskeskus,Tartu.

Yearbook Forest. 2005. Metsakaitse- ja Metsauuenduskeskus, Tartu. 


\title{
Puutuha toime mulla keemilisele koostisele ja noorte männipuude biokeemilistele näitajatele
}

\begin{abstract}
Malle Mandre
On esitatud andmed erinevas koguses puutuhaga $\left(0,0,25 \mathrm{ja} 0,5 \mathrm{~kg} \mathrm{~m}^{-2}\right)$ väetamise tagajärjel toimunud muutustest 20-aastase männipuistu (Põhja-Eesti, Harju maakond, Luige) mulla keemilises koostises ja puude okaste biokeemilistes näitajates (mineraalelemendid, lahustuvad süsivesikud, tärklis, hemitselluloos, ligniin). Puutuha mõju mulla happesusele ja toiteelementide sisaldusele on hinnatud alates eksperimendi algusest 2000. aastal ja selgitatud muutuste ajaline iseloom mulla ülemises, $30 \mathrm{~cm}$ paksuses kihis. On selgunud, et puutuhaga töödeldud muldades tõuseb vastavalt kasutatud puutuha doosidele mulla $\mathrm{pH}$ ja suureneb $\mathrm{K}, \mathrm{Ca}, \mathrm{B}$ ja $\mathrm{Mg}$ kontsentratsioon. Mulla leelistumisega kaasneb $\mathrm{N}-\mathrm{i}$ kontsentratsiooni langus. Okkadiagnostika on näidanud, et muutused puude toitekeskkonnas põhjustavad mitmete toiteelementide akumulatsiooni intensiivistumist ( $\mathrm{K}, \mathrm{Mg}, \mathrm{Fe}, \mathrm{Mn}, \mathrm{Zn}$ ) kudedesse. Kuigi okastes on tõusnud mitmete süsivesikute ainevahetust mõjutavate elementide sisaldus, pole täheldatud statistiliselt olulisi erinevusi lahustuvate süsivesikute ja tärklise sisalduses, mille puhul võib rääkida vaid muutuste tendentsidest. Küll aga on puutuhaga mõjutatud männiokastes suurenenud tselluloosi ja ligniini kontsentratsioon, mille varieeruvus kontrollist sõltub okaste vanusest, arengustaadiumist ja klimaatilistest tingimustest aasta erinevatel perioodidel.
\end{abstract}

